\title{
Exploring Plantation Development and Land Cover Changes in the Meme-Mungo Corridor of Cameroon
}

\author{
Cletus Fru Forba \\ National Advanced School of Public Works Annex Buea, \\ The University of Yaounde I, Cameroon \\ E-mail: Cletusforbafru @gmail.com \\ Jude Ndzifon Kimengsi (Corresponding author) \\ Department of Geography, The University of Bamenda, Cameroon \\ E-mail: jude.kimengsi@catuc.org
}

Received: June 10, 2021 Accepted: August 2, 2021 Published: August 4, 2021

doi:10.5296/ijgs.v5i1.18906 URL: https://doi.org/10.5296/ijgs.v5i1.18906

\begin{abstract}
There is an apparent nexus between the development of plantations and changes in landcover. The Meme-Mungo Corridor is an example par excellence of a tropical plantation corridor in Cameroon which has witnessed significant expansion in tropical plantations of cocoa, banana, rubber and oil palm, among others. This paper analyzes the connection between land cover changes and plantation development over a 42-year period (1960 and 2012). A total of 100 households were sampled using the systematic sampling technique. Furthermore, multispectral data, obtained from the Global Land Cover Facility (GLCF, 2005) were used in the classification of the study area. These images were processed using Geographic Information System (GIS) and Remote Sensing (RS) software and further compiled into a GIS database using ESRI ArcGIS software. The results showed that between 1960 and 2012, a more than $50 \%$ increase in the surface area of plantation crops was registered, leadingto a corresponding change in the land cover situation. Based on this, the study probed into the implications of further plantation development on land cover; further land cover changes could be attributed to the extension of plantations. This paperrecommends among others, the need for intensive agriculture to be encouraged so as to ensure an increase in agricultural output against the backdrop of a decline in agricultural space. Furthermore, augmenting agro-product value chains will stem the loss of agro-produce due to perishability. This will contribute to regulate extensive plantation development in the area.
\end{abstract}


Keywords: Plantation, Development, Land cover dynamics, Meme-Mungo Area

\section{Introduction}

It has been observed that very few landscapes remain on the earth today that have not undergone significant alterations, or have not been subjected to some form of modification by mankind in a bid to satisfy his ever increasing demand (Balgah, 2007; Balgah \& Kimengsi, 2016; Kimengsi et al., 2017). One of the areas through which man has sought to satisfy his socio-economic needs, particularly in developing regions of the world, is through the development of agro-plantations (Kimengsi and Lambi, 2015). The agricultural sector has the potential to serve as an industrial and economic springboard from which a country's development can take off (Ogen, 2007). Indeed, more often than not, agricultural activities are usually concentrated in the less-developed rural areas where there is a critical need for rural transformation, redistribution, poverty alleviation and socio-economic development (Stewart, 2000). The agricultural sector potentially shapes landscapes, and determines the sustainability of natural resources, while contributing to rural livelihoods (Owusu et al. 2021; Kimengsi et al. 2020a, 2020b; Gwan and Kimengsi, 2020). One of the outcomes of the industrial revolution has been the rapid transformation of the agricultural sector. This can be seen through the increasing use of machinery in the cultivation of crops, to boost agricultural productivity. This technological breakthrough has made it possible for farming to be carried out on a very large scale, leading to the creation of agro-industries. However, such agricultural developments, particularly through plantations, lead to land cover changes (Balgah, 2007).

A seemingly unavoidable nexus exists between the development of plantations and changes in land cover. Land cover refers to the observed (bio)-physical cover on the Earth's surface. It includes vegetation and man-made features as well as bare rock, bare soil and inland water surfaces. Land cover is a fundamental element for the description and study of the environment (Herold et al., 2006). It is different from land use which refers to how human beings employ land and its resources (Balgah, 2005). Land cover provides the most useful indicator of human interventions on the land. Land cover changes quickly over time and is a good proxy for understanding the dynamics of the Earth surface resulting from a variety of drivers and factors. At a certain level, land cover provides the common ground for many actors and disciplines interested in land mapping and, thus, provide athe platform to link information between them (Herold et al., 2006). Changes in the ways humans employ the land and its resources result in changes in the earth surface's land cover. It is important to remark that one of the fundamental changes in land cover in most tropical areas could be attributed to the extensification of agriculture through plantation development. This situation is discernable in the Meme-Mungo area of Cameron which could be described as a plantation corridor.

In the Meme-Mungo Area of Cameroon, the same scenario obtains. Here, the development of agro-industries has been a driving force behind land cover dynamics. Due to a number of physical (climate, relief, geology and soils) and human conditions (population, transport connectivity and a ready market) which are favourable for the establishment of plantations, 
these areas have witnessed the establishment of huge industrial plantations of varied cash crop types. The cultivation of large hectares of land by companies like the Cameroon Development Corporation (CDC) and the Plantations du Haut Penja (PHP) has been a spring board to changes in land cover with its attendant implications.

There is an unavoidable connection between the development of plantations and changes in land cover. Fundamental changes in land cover in most tropical areas could be attributed to the extensification of agriculture through plantation development. This situation is discernable in the Meme-Mungo Area of Cameron which could be described as a plantation corridor. While studies have investigated the role of plantations in development (Kimengsi et al., 2016), including the population problem linked to plantation development (Kimengsi \& Lambi, 2015), the role of plantations in precipitating land cover changes have hardly received significant research attention. This particularly concerns the Meme-Mungo area of Cameroon. The Meme-Mungo Area is an example par excellence of a tropical plantation corridor in Cameroon which has witnessed significant expansion in tropical plantations of cocoa, banana, rubber and oil palms, among others. For instance, between 1960 and 2012, a more than 50\% increase in the surface area of plantation crops was registered. This led to a corresponding change in the land cover situation. The implications of such rapid growth are widespread as concerns environmental and human related factors. This paper seeks to establish a link between plantation development and land cover changes, and suggests ways of introducing land management practices that will curb the rate of land cover change which, by implication, refers to alterations in the biophysical environment.

\section{Literature Review}

In identifying changes in agricultural practices and landscape in Lampung area in southern Sumatra, Imbernon (1999) noted that agricultural practices can have a marked effect on land cover and landscape over time. These changes were characterized using maps from 1930, 1969 and 1985, and a 1996 satellite image to understand the dynamics of the slash-and-burn agriculture over time. In 1930, shifting cultivation was practiced along rivers and forest cover was high (77.5\%). Between 1969 and 1985 major changes occurred and the forest area was reduced to $10 \%$. A massive front of clearing moved from the southwest with the transmigration programme and the development of the agro-industrial plantations. Finally, in 1996, there was no more forest and the landscape was shaped by cleared land for small farms in transmigration areas and by large industrial plantations.

An understanding of changes in land use and land cover has always been a fundamental issue of interest to geographers. This is receiving much attention thanks to advancements in science and technology (Mertens \& Lambin, 2000). A distinction could be made between land cover and land use. To Herold et al. (2006), land cover refers to the observed (bio)-physical cover on the earth's surface. It includes vegetation and man-made features as well as bare rock, bare soil and inland water surfaces. Land use on the other hand, refers to how human beings employ land and its resources (Balgah, 2005). Although these two terms are used to denote different things, they are indeed difficult to separate because of their interconnection; land use changes evidently lead to a change in the existing land cover of an area. In another dimension, land cover corresponds to that which overlays or currently covers the ground (Di Gregorio \& Jansen, 1997). Land use distinctions can be made on the basis of its functional 


\section{Ml Macrothink}

dimension which corresponds to the description of areas in terms of their socio-economic purpose: areas used for residential, industrial or commercial purposes for farming or forestry, for recreational or conservation purposes, etc., or in terms of its sequential dimension which relates to a series of operations on land, carried out by humans, with the intention to obtain products and/or benefits through using land resources. For example, a sequence of operations such as ploughing, seeding, weeding, fertilizing and harvesting in the agricultural sector (Mücher et al., 1993).

Links with land cover are possible; it may be possible to infer land use from land cover and conversely. But situations are often complicated and the link is not so evident. Land cover and land use change is commonly divided into two broad categories: conversion (a change from one cover or use category to another such as from forest to grassland) and modification (a change within one land use or land cover category such as from rain fed cultivated area to irrigated cultivated area due to changes in its physical or functional attributes) (Stott \& Haines-Young, 1996; Alun \& Clark, 1997; Baulies, \& Szejwach, 1997).

\section{Study Area and Research Methods}

The study area falls within the South West and Littoral Regions of the Republic of Cameroon (Figures 1 \& 2). Geographically, it is located between latitudes $4^{\circ} 10^{\prime}-4^{\circ} 50^{\prime}$ North of the Equator, and longitudes $9^{\circ} 20^{\prime}-9^{\circ} 50^{\prime} \mathrm{E}$ of the Greenwich meridian.

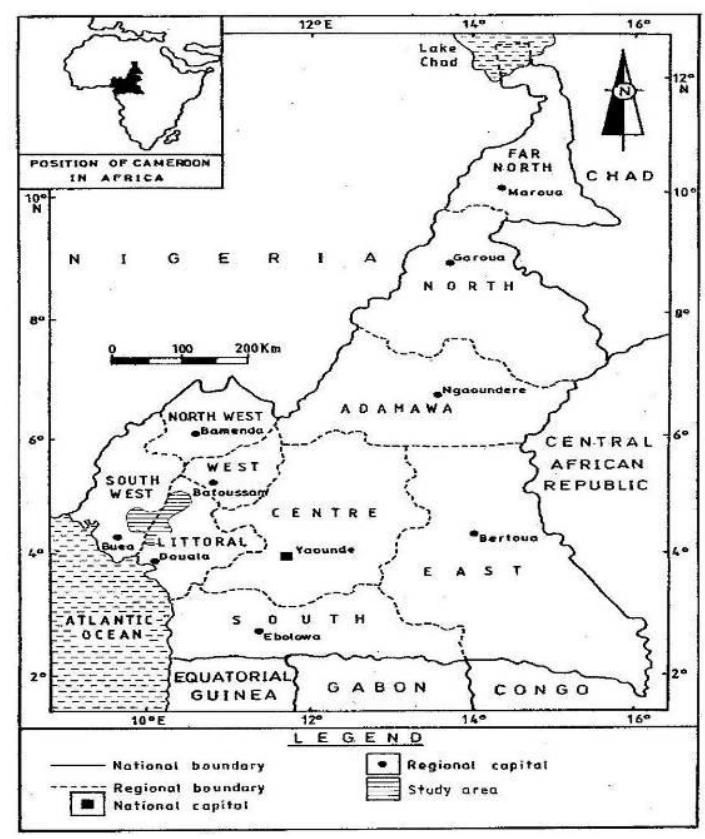

Figure 1. Location of the Study Area in Cameroon

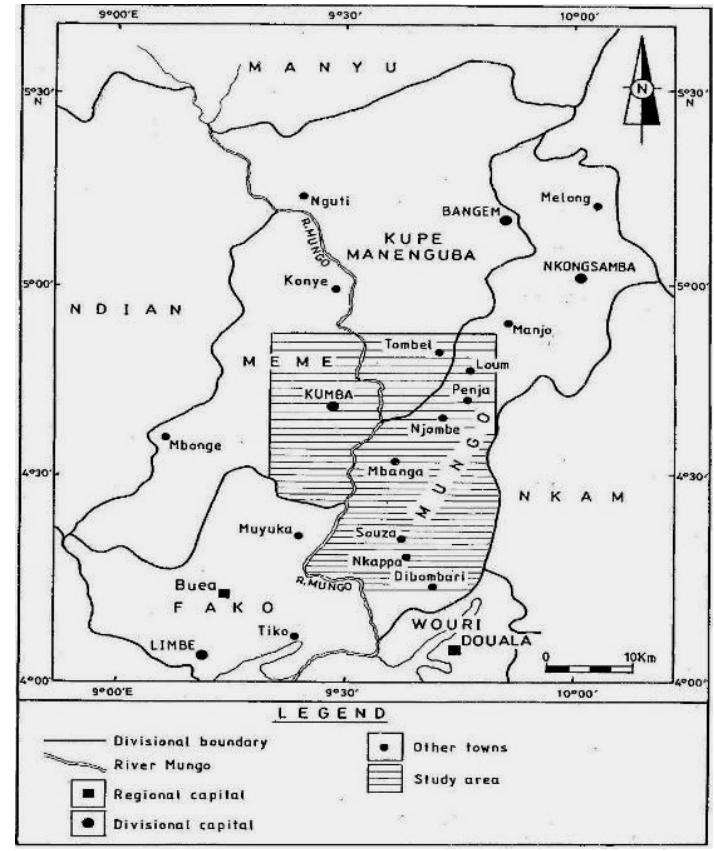

Figure 2. Meme-Mungo Area of Cameroon

In the South West Region, the study area falls within Meme Division, and in the Littoral Region, it falls within the Mungo Division. The major settlements in the area include Kumba, Tombel, Etam, Ediki in Meme Division, and Loum, Penja, Njombe, Mbanga, Nkapa and Souza in the Mungo Corridor. Most of these settlements are situated along the 


\section{Macrothink}

Douala-Bafoussam highway, which is one of the major road axes in the country. In addition, the study area is traversed by one of the largest and most regular river in the country, rendering the region fertile for plantation agriculture and food crop cultivation. The study area is characterized by a very dense population that is scattered in various settlements (Table 1).

Table 1. Population of Towns in the Meme-Mungo Area

\begin{tabular}{ll}
\hline Town & Population \\
\hline Loum & 39,707 \\
Njombe-Penja & 31,792 \\
Mbanga & 35,415 \\
Nkapa- Souza & 17,141 \\
Ikiliwindi & 5,100 \\
Kumba & 166,331 \\
Tombel & 57,017 \\
Etam & 5,000 \\
Ediki & 4,600 \\
\hline
\end{tabular}

Source: BUCREP, 2005; Village Reports, 2011.

A total of 100 households were sampled using the systematic sampling technique. Furthermore, multispectral data obtained from the Global Land Cover Facility (GLCF, 2005) were used in the classification of the study area The multispectral data used in the classification of the study area is obtained from Landsat (MSS, TM and ETM+) sensors. The data for multispectral images ranged from visible (VIS; $0.45-0.9 \mu \mathrm{m}$ ), near-infrared (NIR; $0.76-0.98 \mu \mathrm{m}$ ), mid-infrared/short wave infrared (MIR/SWIR; $1.55-2.35 \mu \mathrm{m}$ ) to thermal infrared (TIR; 10.4 - 12.5). These images were obtained from the Global Land Cover Facility (GLCF, 2005) and they were processed using Geographic Information System (GIS) and Remote Sensing (RS) software, and compiled into a GIS database using ESRI ArcGIS software. Secondary data was obtained by reviewing already published materials related to the work from libraries, text books, journals, articles, magazines and reports from the main agro-industrial complexes operating within the study areas. These include, the Cameroon Development Corporation (CDC), PHP, Societé des Plantations de Mbanga (SPM) and Société Camerounaise de Palmeraies (SOCAPALM). Information was also obtained from the Municipal Councils, Regional Delegations of Urban Affairs, Town Planning and Housing, Territorial Administration, and L'Institut de Recherche Agricole pour le Développement (IRAD). Finally, this study made use of internet sources for intensive literature review on issues related to plantation development and land cover changes. 


\section{Macrothink

\section{Results}

\subsection{Plantation Development}

From the results obtained, it was observed that an increase in the number of plantations, the expansion of existing plantations and the growth of smallholder schemes are crucial indicators of plantation development in the Meme-Mungo Area (Figure 3). The presence of major agro plantations in this area encouraged the development of smallholder schemes since small holders benefit from the technical expertise of the major plantations and also acquire seedlings (formally and informally) from the major plantations. In addition, the produce from smallholders is sold to the main companies almost invariably, except in cases where smallholders have processing units.

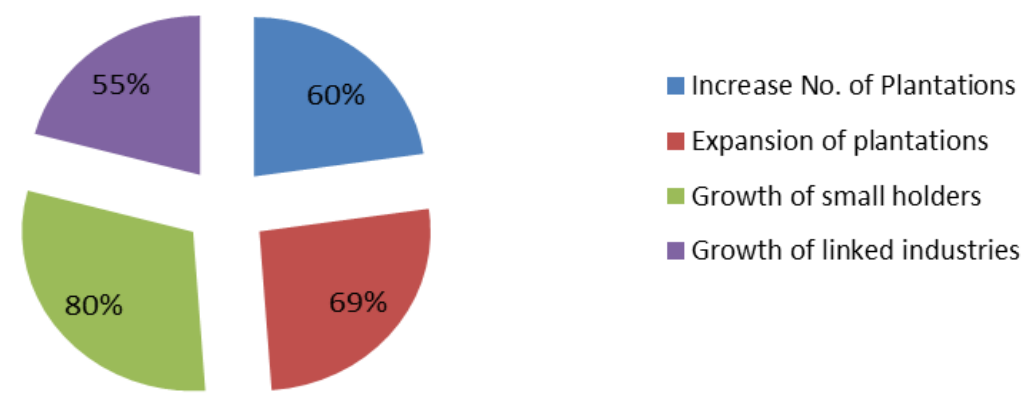

Figure 3. Indicators of Plantation Development in the Meme-Mungo Area

As earlier indicated, a more than 50\% increase in the surface area of plantations has been registered between 1960 and 2012. This has systematically altered the land cover situation as is viewed through the land cover maps for 1975, 1986 and 2012.

\subsection{Land cover Situation for the Meme-Mungo Area (1975)}

The land cover situation for the Meme - Mungo Area in 1975 indicates that much of the land was still covered by the forest. In the second place was the presence of plantations while settlement land use was timidly present (Figure 4). 


\section{Macrothink}

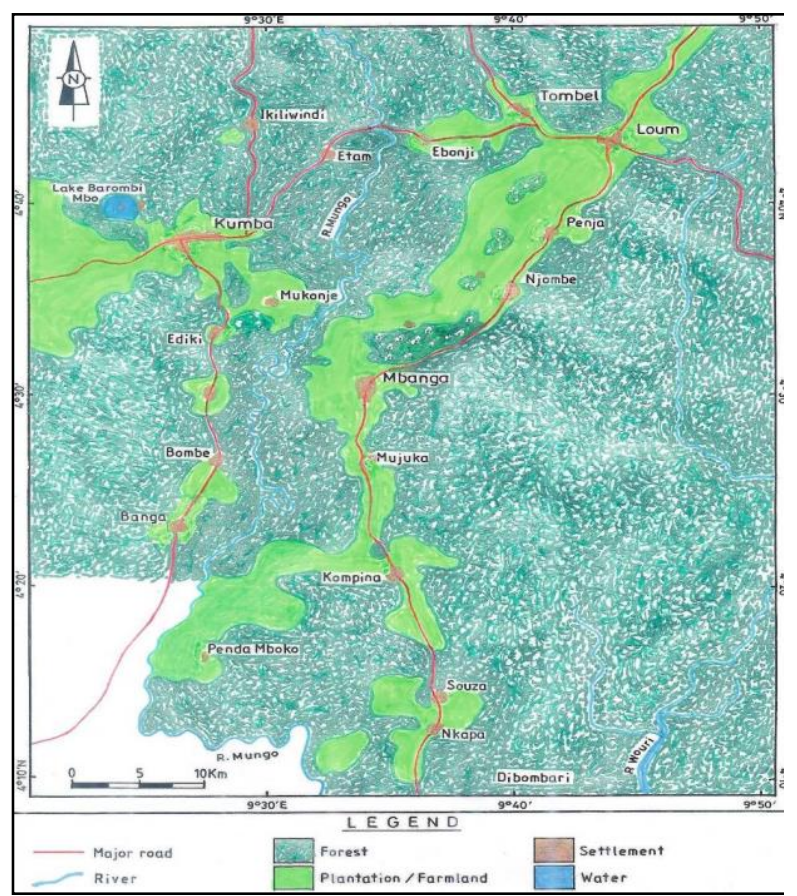

Figure 4. Land cover situation for the Meme-Mungo Area in 1975

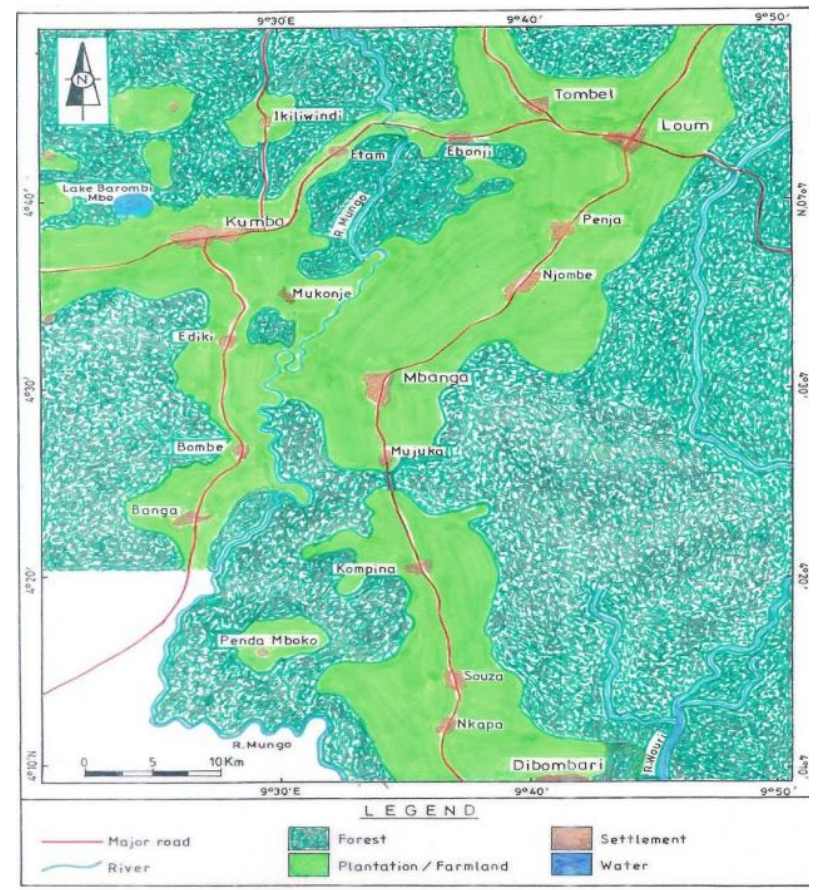

Figure 5. Land Cover for the Meme - Mungo Area in 1986

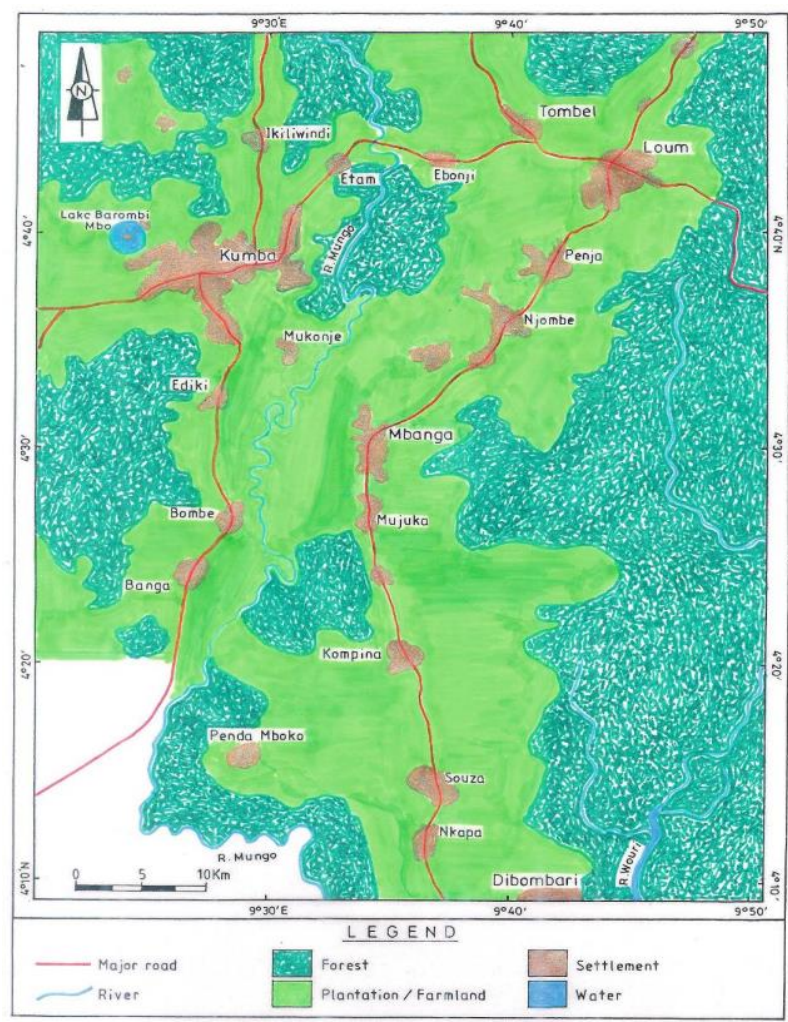

Figure 6. Land cover for the Meme-Mungo Area in 2012 
5.3 Land Cover Situation for the Meme - Mungo Area in 1986

The situation for 1986 shows a significant extension of plantation/agricultural land use into the areas previously covered by forest. This indicates the extension of agriculture through the expansion of existing plantations and the creation of new ones (Figure 5).

\subsection{Land cover Situation for the Meme-Mungo Area in 2012}

In 2012, significant expansion of settlement land use was observed. This indicates the essential role of plantations in the urbanization process (Figure 6).

Between 1960 and 2012, a more than 50\% increase in the surface area of plantation crops was registered. This led to a corresponding change in the land cover situation; in 1975, the land cover situation stood at $485 \mathrm{sq} \mathrm{km}$, it moved to $675 \mathrm{sqkm}$ in 1986 and by 2012, the situation stood at $1350 \mathrm{sq} \mathrm{km}$ (Table 2).

Table 2. Land Cover changes for the Meme-Mungo Area (1975 - 2012)

\begin{tabular}{llll}
\hline \multicolumn{4}{l}{ Year/surface area } \\
\hline Land cover type & 1975 & 1986 & 2012 \\
Forest & 3317 & 3310 & 2363.7 \\
Plantation & 485 & 675 & 1350 \\
Settlement & 31.3 & 46.8 & 118.8 \\
Water & 12.5 & 12.5 & 12.5 \\
\hline
\end{tabular}

Source: Deduced from land cover maps of 1975, 1986 \& 2012.

\section{Conclusion and Recommendations}

This study examined the relationship between plantation development and land cover change in the Meme - Mungo Area. From the investigation, the following conclusions can be drawn: a more than $50 \%$ increase in plantations coverage has been registered in the Meme-Mungo Area between 1960 and 2012. This increase has led to changes in land cover with plantation and settlement coverage gradually significantly converting forest and water land coverage. Based on the changes observed, one could deduce two possible land cover scenarios for the Meme-Mungo Area; a situation of further land cover change in which plantations will continue to convert the natural forest. Such a situation will be accompanied by an increase in the settlement coverage and a reduction in water cover. Scenario two which is presented based on the underlying recommendations will result in a situation of reduced plantation expansion and coordinated residential developments. Such a scenario will control the rate of land cover change, especially forest cover. Although the study has reported these changes, it is plausible to submit that further studies are required to provide fresh evidence on the state of land cover changes, especially as the Mungo Corridor has recently received significant waves of migrants originating from the South West and North West Regions, due to the ongoing Anglophone crisis. Such studies would not only reveal new patterns of land use and land cover change, but could profoundly explain their implications for growth and development in this area. Based on the above conclusions, the following recommendations are proposed: 
- Effective monitoring and assessment of the environmental impact of land cover changes are necessary in the study area. This will assist stakeholders to properly plan and adopt land management approaches that will assist in conserving the environment.

- It is also recommended that intensive agriculture should be encouraged so as to ensure an increase in agricultural output against the backdrop of a decline in agricultural space. This should be controlled by agricultural field technicians to ensure proper land management and improved yields.

- In some areas, it is suggested that the plantations should opt for industrial transformation of their products to add value and raise more income rather than depending so much on expanding plantations. This will improve on the agricultural value chain.

- Furthermore, the uncontrolled growth of small holder plantation schemes should be checked as this has been blamed on the constant alteration of the existing land cover situation. More coordinated developmental options would offer a more plausible solution to the increasing land cover alteration.

\section{Acknowledgement}

We acknowledge the respondents who took time to respond to the interviews conducted.

\section{References}

Ako, A. A., Shimada, J., Kimpei, I., Katsuaki, K., Takahiro, H., Takem, G. E. E., \& Iskandar, I. (2010). Hydrochemical and isotopic characteristics of water resources in the Banana Plain (Mungo Division) Cameroon. In Zuber A., Kania, J. and Kmiecik E. eds (2010): XXXVIII IAH Congress on Groundwater Quality Sustainability, Krakow, 12-17 Sept 2010, Extended Abstract id: 168, University of Silesia Press 2010, Krakow, Poland.

Alun, J., \& Clark, J. (1997). Driving forces behind European land use change: an overview. CLAUDE Resource Paper No.1

Balgah, S. N., \& Kimengsi, J. N. (2016). Land Use Dynamics and Wetland Management in Bamenda: Urban Development Policy Implications. Journal of Sustainable Development, 9(5), 1-11. https://doi.org/10.5539/jsd.v9n5p141

Balgah, S. N. (2005). Land use and Land Cover Dynamics in Buea and Tiko Sub Divisions, Cameroon. Unpublished Ph.D Thesis, University of Buea, Department of Geography

Balgah S. N. (2007). Population Growth and Land Use Dynamics in Buea Urban Area, Cameroon. Loyola Journal of Social Sciences.

Baulies, X. I., \& Szejwach, G. (ed.) (1997). Survey of needs, gaps and priorities on data for land use and land cover change research. LUCC Data requirements workshop, Barcelona 11-14 November 1997, LUCC report series 3

Di Gregorio, A., \& Jansen, L. J. M. (1997). A new concept for a Land Cover Classification System. Earth observation and evolution classification, 1997, Conference Proceedings. 13-16 October 1997, Alexandria, Egypt, 10p.p.

Global Land Cover Facilities (GLCF) WEBSITE, 2005, Available online at http://glcfapp.umiacs.umd.edu/index.shtml

GTZ (2006). Projet pour l'Amelioration de l'acces a l'eau potable et de l'assainissement de 
base dans les trios communes rurales de Manjo, Loum et Penja/Njombe, Province de Littoral-Cameroun. Douala-Cameroon: German Technical Cooperation,

Gwan, A. S., \& Kimengsi, J. N. (2020). Urban Expansion and the Dynamics of Farmers' Livelihoods: Evidence from Bamenda, Cameroon. Sustainability, 12(14), 5788. https://doi.org/10.3390/su12145788

Herold, M., Latham, J. S., Digregorio, A., \& Schmullius, C. C. (2006). Evolving standards in land cover characterization. Journal of Land Use Science, 1, 157-168. https://doi.org/10. 1080/17474230601079316

Imbernon, J. (1999). Changes in agricultural practice and landscape over a 60-year period in North Lampung, Sumatra, CIRAD/ICRAF Joint Research Project, Montpellier, France. https://doi.org/10.1016/S0167-8809(99)00060-2

Kimengsi, J. N., Mukong, A. K., \& Balgah, R. A. (2020a). Livelihood diversification and household well-being: Insights and policy implications for forest-based communities in Cameroon. Society and Natural Resources, 33(5), 1-21. https://doi.org/10.1080/08941920. 2020.1769243

Kimengsi, J. N., Balgah, R. A., Buchenrieder, G., Silberberger, M., \& Batosor, H. P. (2020b). An empirical analysis of credit-financed agribusiness investments and income poverty dynamics of rural women in Cameroon, Community Development, 51(1), 72-89. https://doi.org/10.1080/15575330.2020.1716031

Kimengsi, J. N., Balgah, S. N., \& Achia S. N. (2017). Peri-Urban Land use Dynamics and Development Implications in the Bamenda III Municipality of Cameroon. Sustainability in Environment, 2(3), 273-288. https://doi.org/10.22158/se.v2n3p273

Kimengsi, J. N., Lambi J. N., \& Gwan S. A. (2016). Reflections on the Role of Plantations in Development: Lessons from the Cameroon Development Corporation (CDC). Sustainability in Environment, 1(1), 1-11. https://doi.org/10.22158/se.v1n1p1

Kimengsi, J. N., \& Lambi, C. M. (2015). Pamol Plantations Plc: Prelude to a Looming Population Problem in Ekondo Titi Sub-Division, South West Region of Cameroon. Journal of Sustainable Development in Africa, 17(3),79-94.

Mücher, C. A., Stomph, T. J., \& Fresco L. O. (1993). Proposal for a global land use classification FAO, Rome.

Mertens, B., \& Lambin, E. F. (2000). Land-cover-change Trajectories in Southern Cameroon. Annals of the association of American Geographers, 90(3), 467-494. https://doi.org/10.1111/ 0004-5608.00205

Nasreen M., Hossain, K. M., \& Kundu, D. K. (2006). The Interrelationship between Poverty, Environment and Sustainable Development in Bangladesh: An Overview.

Ogen, O. (2007). The Agricultural Sector and Nigeria's Development: Comparative Perspectives from the Brazilian Agro-Industrial Economy, 1960-1995.

Owusu, R., Kimengsi, J. N., \& Moyo, F. (2021). Community-based Forest Landscape Restoration (FLR): Determinants and Policy Implications in Tanzania. Land Use Policy, 109(2021), 105664. https://doi.org/10.1016/j.landusepol.2021.105664

Rajalahti, R. (2006). Promoting Agricultural Innovation Systems Approach: The Way 


\section{Macrothink}

Forward, the World Bank

Stewart, F. (2000). Income Distribution and Development, QEH Working PaperNo. 37, Queen Elizabeth House Oxford University.

Stott, A., \& Haines-Young, R. (1996). Linking land cover, intensity of use and botanical diversity in an accounting framework in the UK.

\section{Copyright Disclaimer}

Copyright for this article is retained by the author(s), with first publication rights granted to the journal.

This is an open-access article distributed under the terms and conditions of the Creative Commons Attribution license (http://creativecommons.org/licenses/by/4.0/). 